\title{
Entrepreneurial identity and farmers' protein crop cultivation choices
}

\section{Suvanto, Hannele}

2020-04

Suvanto , H , Niemi , J K \& Lahdesmaki , M 2020 , ' Entrepreneurial identity and farmers' protein crop cultivation choices ' , Journal of Rural Studies , vol. 75 , pp. 174-184 . https://doi.org/10.1016/j.jrurstud.2

http://hdl.handle.net/10138/339438

https://doi.org/10.1016/j.jrurstud.2020.01.022

cc_by_nc_nd

acceptedVersion

Downloaded from Helda, University of Helsinki institutional repository.

This is an electronic reprint of the original article.

This reprint may differ from the original in pagination and typographic detail.

Please cite the original version. 


\title{
Entrepreneurial identity and farmers' protein crop cultivation choices
}

\begin{abstract}
Protein crops are important in enhancing sustainable and self-contained agriculture and food security in Europe. Individual farmers are key players in protein crop production. The aim of this research is to understand how an entrepreneurial identity affects strategic cultivation decisions in the context of protein-rich crop farming. In this study, entrepreneurial identity consists of a farmer's personal and entrepreneurial orientations. Data on 308 Finnish farmers were gathered and statistically tested. Our findings clarify that entrepreneurial identity increases the probability of beginning protein-rich crop cultivation, especially if the farmer in question is innovative, a risk-taker and highly educated. This article contributes to the understanding of agricultural entrepreneurship and strategic cultivation decisions made by different kinds of farmers. We further claim that profitable but risky and demanding crops have tempted farmers with a high entrepreneurial identity for the most part, which would not suffice for protein crops to become mainstream.
\end{abstract}

Keywords: Entrepreneurial identity, Entrepreneurial orientation, Personal orientation, Entrepreneurialism, Farmer, Protein crop

\section{Introduction}

The ecological challenges associated with industrialized food production, such as loss of biodiversity, have increased the demand for plant-based protein sources (Goodland, 1997; Rubiales and Mikic, 2015). Protein-rich crops deliver environmental benefits by supporting above- and below-ground 
biodiversity, including that of pollinating insects (Bues et al., 2013). They further contribute to sustainable agriculture by biological nitrogen fixation, reducing energy costs and improving soil physical conditions (Robson et al., 2002; Sillero et al., 2010), duly contributing to lower emissions of greenhouse gases and acidic substances (Bues et al., 2013). In addition to their positive environmental effects, protein-rich crops are an important and essential source of protein for food and particularly for feed (e.g. Stagnari et al., 2017). Despite their well-acknowledged role in sustainable agriculture, the production of protein-rich crops has been decreasing in Europe, representing only $1.8 \%$ of arable land in 2011 compared with $4.7 \%$ in 1961. Europe is heavily dependent on the import of plant-based protein supplies. Reversing the decline of protein-rich crop production to improve the environment and address the risks arising from dependence on imported protein sources is thus one of the main sustainability objectives related to European agriculture and food systems (EU, 2013).

Farmers play a significant role in enabling the transformation towards more sustainable plant-based protein production. Even though the EU's agricultural policy encourages the production of proteinrich crops, and the production provides benefits for farmers as the crop requires little or no nitrogen fertilizer (Bues et al., 2013), the production of protein-rich crops can be challenging. Such crops are considered to be unstable and less competitive against weeds when compared to cereal production (e.g. Robson et al., 2002; Sillero et al., 2010). The undeveloped market, limited knowledge of cultivation methods and a lack of self-efficacy can also hinder farmers' willingness to cultivate these crops (Suvanto et al., 2018). A relevant reason for farmers not to cultivate protein-rich crops is related to their propensity for avoiding risks (ibid.)

Entrepreneurial identity can be an important factor explaining farmers' willingness to start cultivating new crops (e.g. De Rosa et al., 2019; McElwee, 2006). Still, the mainstream entrepreneurship research has largely overlooked the agricultural sector, and the significance of identity in entrepreneurial motivation processes has remained unaddressed for the most part (Fitz-Koch et.al., 2018). There is an 
entrepreneurial paradox within the context of agriculture: farmers are encouraged to identify themselves as entrepreneurs, yet a discrepancy exists. Farmers often have scant personal or entrepreneurial capabilities to respond to changing market demands, and have limited opportunities to act strategically, but they have to take many risks and have little power to influence the food chain (Phillipson et al., 2017; Thompson et al., 2019). In this complex situation, the individual farmer and his or her characteristics become a key factor in the ability to succeed. Accordingly, there is a need to understand individual farmers' entrepreneurial identity in relation to their decision-making (e.g. De Rosa et al. , 2019; Grande et al., 2011; Shane, 2003; Wiklund and Shepherd, 2005; Woldesenbet et al., 2011). In this study, we aim to fill this research gap by examining in greater detail the relationship between farmers' entrepreneurial identity and their decision to grow protein-rich crops.

In our theoretical framework, we divide entrepreneurial identity into entrepreneurial orientation and personal orientation. We observe that entrepreneurial orientation can be understood as conceptualizations of an individual's traits but, unlike the dimensions of personal orientation, the dimensions of entrepreneurial orientation can also be used as characteristics of organization. Accordingly, entrepreneurial orientation consists of certain dimensions such as willingness to innovate, take risks and behave proactively (Lumpkin and Dess, 1996), as well as pursue growth in the farm context (Carland et al., 1984; Stevenson and Jarrillo-Mossi, 1986; Vesala and Vesala, 2010). In addition, studies have emphasized personal orientation such as an entrepreneur's belief in personal control, self-efficacy and optimism as key factors in an active, enduring and successful business (Bird, 1989; Carland et al., 1984; McCelland, 1961; Rotter, 1966). Since the relationship between an individual farmer, a business and the rural environment is unique and complex (Carter and Rosa, 1998; Grande et al., 2011; Mc Fadden and Gorman, 2016; McNally, 2001), taken together the two theoretical views - the entrepreneurial and personal orientations - reveal a plethora of farmers' entrepreneurial identities and crop cultivation choices (e.g. Fitz-Koch et al., 2018). 
We limit our research to four protein-rich crops, namely field pea [Pisum sativum L.], faba bean [Vicia faba L.], turnip rape [Brassica rapa L.] and oilseed rape [Brassica napus L.]. Oilseeds are very important protein-rich crops across the whole EU and particularly in Finland, while field pea and faba bean are important mainly in Northern Europe (Peltonen-Sainio and Niemi, 2012). Finland provides an interesting research context since there is an economic and environmental potentiality to expand the production significantly (Peltonen-Sainio and Niemi, 2012, p. 361). Oilseeds have commonly been cultivated since the 1970s and their markets are well developed and stable (Pahkala, 1989). Legumes, on the other hand, have been cultivated for centuries but in small amounts and for on-farm use (Stoddard et al., 2009). Both legumes and oilseeds are minor crops, with their total domestic production yielding only 2-3 per cent of crop-based raw protein used in Finland (Kaukovirta-Norja et al., 2015).

This study addressed the following research question: Does an entrepreneurial identity affect farmers' propensity to cultivate protein-rich crops? In order to provide an answer, we first compared the entrepreneurial identity of protein crop farmers and farmers without experiences of protein crop cultivation. We hypothesize that farmers with a strong entrepreneurial identity (i.e. a high propensity for risk-taking, innovation, growth, self-efficacy, personal control and optimism) are more likely to cultivate protein-rich crops compared with those with a low entrepreneurial identity. Secondly, we compared the differences in entrepreneurial identity between legume farmers, oilseed farmers and those cultivating both legumes and oilseeds. Due to the more developed and stable markets for oilseeds, we suggest that farmers cultivating turnip rape and oilseed rape foresee fewer risks when compared with legume farmers. We thus hypothesize that farmers cultivating legumes have a stronger entrepreneurial identity compared with those farmers cultivating other protein-rich crops. 
The contributions of our study are twofold. First, our results indicate that entrepreneurial identity contributes positively to the cultivation of protein-rich crops. Our research extends agricultural entrepreneurship research and its theoretical basis of strategic management by applying an approach that integrates the entrepreneurial and personal orientations. Second, our study reveals the gap between political expectations and cultivation choices made by farmers. The protein market structures are generally underdeveloped in Finland and protein-rich crop cultivation only engages the attention of farmers with a high entrepreneurial identity. This hinders the shift from niche to mainstream farming and hampers the development of environmentally sustainable farming. Therefore, we suggest that policy measures should encourage farmers with a lower entrepreneurial identity to increase protein crop production.

The rest of the paper is structured as follows. First, we present the concept of entrepreneurial identity by examining the literature concerning entrepreneurial and personal orientations. Second, we discuss the methodological approach and statistical analysis. After this, we introduce the results of the study by demonstrating the influence of entrepreneurial identity on protein crop cultivation strategies. We base the discussion on the dialogue between the study findings and previous research. Finally, the findings are concluded with insights, possible implications and the limitations of the study.

\section{Theoretical framework: Farmers as entrepreneurs}

Today farmers are increasingly expected to operate in a competitive environment as innovative and risk-taking business owners, as distinct from merely being food producers (Fitz-Koch et al., 2018; McElwee, 2006; Pindado and Sánchez, 2018; Silvasti, 2009). Concurrently, a significant part of farmers' revenues is determined through agricultural subsidies which can enhance the producer identity (Stenholm and Hytti, 2014). The producer identity relies on traditional farming strategies, risk 
avoidance, continuity of generation and the idea of surviving but not profit maximization (e.g. Stenholm and Hytti, 2014; Niska et al., 2012; Burton and Wilson, 2006). Even though producer identity is strongly ingrained in Finnish farmers, the idea of entrepreneurship is neither unfamiliar nor unpleasant for them (Niska et al., 2012; Stenholm and Hytti, 2014; Vesala and Vesala, 2010). Farmers may reject the notion of entrepreneurship when it is defined as profit maximization, but they highly appreciate entrepreneurship when it is understood from a psychological point of view, especially as autonomy and personal control (Niska et al., 2012). Thus, these psychological aspects need to be taken into consideration when examining farmers' entrepreneurial identities. For example, Robinson et al. (1991), Vesala et al. (2007), Gellynck et al. (2015) and De Rosa et al. (2019) integrate the psychological and the traditional entrepreneurial orientation aspects in order to better understand entrepreneurial identity formation. We will adopt a similar theoretical approach to studying farmers' entrepreneurial identity by dividing it into entrepreneurial orientation and personal orientation.

\subsection{Entrepreneurial orientation}

The concept of entrepreneurial orientation is a novel theoretical tool within agriculture, which has received increasing attention in the literature in recent years (Dias et al., 2019a; Fitz-Koch et al., 2018). Nevertheless, researchers have recognized the need to better understand the circumstances whereby an increase in entrepreneurial orientation can lead to increased performance or strategic actions (Gellynck et al., 2015; Hughes and Morgan, 2007; Veidal and Flaten, 2014; Wiklund and Shepherd, 2005). In the farming context, where structural changes, small businesses, strict regulations and high risks are common, an entrepreneurial orientation is similarly associated with the aim of surviving and adapting (Stevenson and Jarillo, 2007). Lumpkin and Dess (1996) specify that an entrepreneurial orientation represents the process, decision-making styles and methods that inform how entrepreneurially an organization or an individual reacts to changes in the business environment. In small businesses, like farms in Finland, the organizational and individual level can be regarded as one 
and the same because "the small business form is simply an extension of the individual who is in charge" (Lumpkin and Dess, 1996, p. 138). The individual farmer is the key player in strategic decisions and actions taken on the farm (e.g. Pindado and Sánchez, 2018; Stevenson and Jarrillo-Mossi, 1986; Vesala and Vesala, 2010; Vesala et al., 2007, De Rosa et al., 2019) and this analysis therefore focuses on the individual farmer's entrepreneurial orientation.

According to Lumpkin and Dess (1996), entrepreneurial orientation consists of five dimensions: risktaking, innovativeness, proactiveness, competitive aggressiveness, and autonomy. However, researchers commonly recognize only three dimensions of entrepreneurial orientation as characterized by Covin and Slevin (1991) based on Miller's (1983) conceptualization: innovativeness, proactiveness and risk-taking. Innovativeness reflects a tendency to support new ideas, novelty, experimentation and creativeness (Lumpkin and Dess, 1996; Miller, 1983; Wiklund and Shepherd, 2005). Proactiveness means anticipating, acting for the future, having a forward-looking perspective, being a first- or early-mover and therefore creating a competitive advantage by recognizing emerging opportunities (Lumpkin and Dess, 1996; Miller, 1983; Woldesenbet et al., 2011). Risk-taking is associated with the willingness to take risks even though the cost of failure may be high and outcomes unknown (Woldesenbet et al., 2011).

We suggest that innovativeness is demonstrated in farmers' new protein crop cultivations. The cultivation experiment, for example, means creating novel cultivation techniques, which are strongly associated with the strategies of one's own farm such as on-farm feed production or organic farming (Robson et al., 2002; Suvanto et al., 2018). Similarly, risk-taking is related to new protein crops because the harvest and sale are uncertain, knowledge and skills for protein crop cultivation are often substandard, and failure means financial losses for farmers (Peltonen-Sainio et al., 2013; PeltonenSainio and Niemi, 2012; Suvanto et al., 2018). Moreover, Trujillo-Barrera et al. (2016) suggest that perceived risk is a barrier to the adoption of sustainable practices, and risk tolerance is a positive 
moderator of the relationship between economic rewards and adoption. Interestingly, protein crop cultivation can also be seen as risk-reducing action: large farms may reduce risk by cultivating many different plants (Mishra and Lence, 2005; Peltonen-Sainio and Niemi, 2012). In the farm context, innovativeness and risk-taking are often closely interlinked with farmers' proactiveness because they have a positive influence on farm performance (Verhees et al., 2011). Proactiveness demonstrates the future-looking perspective such as forecasting consumer behaviour and market needs, responsiveness to market signals and competitors, and being a first-mover (Lumpkin and Dess, 1996; Miller, 1983; Woldesenbet et al., 2011). However, farmers may still have limited opportunities to respond to the needs of consumers since they can seldom influence the food processing industry (e.g. Carter and Rosa, 1998; Phillipson et al., 2004). Thus, even though seeking profitable new crops can be interpreted as proactive behaviour and a way for farmers to respond to market signals, it might also be a way to increase the sense of personal control (Suvanto et al., 2018). Due to the challenges associated with the concept of proactiveness in the farm context (e.g. McElwee and Smith, 2012), we did not use it as an independent measure to examine farmers' entrepreneurial orientation.

Growth orientation and scale enlargement are characteristics typically associated with entrepreneurship (Carland et al., 1984; Stevenson and Jarrillo-Mossi, 1986), but they also reflect the continuation of farms (Carter and Rosa, 1998; Vesala and Vesala, 2010; Viira et al., 2014) and rewards of entrepreneurial behaviour (Fitz-Koch et al., 2018; Grande et al., 2011; Luke, 2019; Lumpkin and Dess, 1996). In Finnish farms, the average farm size has increased significantly in recent decades (Luke, 2018). The contemporary and continuing growth of Finnish farms cannot, however, be taken as a direct indicator of intensifying entrepreneurialism. Stenholm and Hytti (2014) in their study on Finnish farming identities show that a growth orientation can also be built on a traditional producer ethos, and hence farm growth is not perceived as a goal in itself but merely as a means of survival. Similarly, Rizov and Mathijs (2003) claim that the meaning of size in farm survival is relevant. However, growth orientation, risk-taking and innovativeness are neither unequivocal nor merely associated with 
entrepreneurship, but can be combined with entrepreneurship in the agricultural sector (e.g. McElwee, 2006; Vesala et al., 2007).

\subsection{Personal orientation}

Farming is associated with entrepreneurship and farmers are therefore required to sense and seize opportunities and to transform and reconfigure opportunities into business (e.g. Arthurs and Busenitz, 2006). However, the key question is why some farms explore and/or exploit their resources better than others. We suggest the answer lies in the fact that a farm reflects the respective farmer's personality, which is more enduring than an entrepreneurial orientation that can be influenced by education and knowledge. The role of personality in entrepreneurship is undeniable (Rauch and Frese, 2007; Zhao and Seibert, 2006). Consequently, in this study we use personal control, self-efficacy and optimism as the dimensions of personal orientation, which can be considered to represent the core of the theoretical discussion concerning the nature of personality in entrepreneurial identity (e.g. Bandura, 1977; Vesala et al., 2007).

Entrepreneurial personality includes the idea of intentional, active farmers who believe they can influence actions in order to achieve their interests and who believe that they have the capabilities to achieve these interests. Indeed, individuals with a strong internal locus of control believe that events in their life derive primarily from their own actions (Rotter, 1966). The locus of control forms the framework of Rotter's (1966) social-learning theory of personality psychology, referring to the fact that the outcomes of events are either within or beyond an individual's personal control, although personal control does not mean behavioural causality per se (Bandura, 1977; Rotter, 1966). Personal control is a significant factor in achieving an active, persistent and successful business (Shane, 2003). For example, farmers with limited opportunities to choose their customers have weaker personal control (Nousiainen et al., 2009; Vesala and Peura, 2005). Still, farmers have opportunities to influence 
their business activities, for example by making cultivation decisions, thereby increasing their sense of personal control.

The term 'self-efficacy', as defined by Bandura (1986), means that a person believes he or she has the capabilities to achieve a desirable objective (Boyd and Vozikis, 1994). Previous literature has shown that entrepreneurs have a stronger belief in their opportunities to exert an influence and in their selfefficacy than people on average (Bandura, 1997; Chen et al., 1998). However, we should distinguish between an individual's efficacy expectancy and their outcome expectancy, which is a belief about the consequences of a particular behaviour, even though in practice they often have a joint effect (Peterson and Stunkard, 1992). In the farm context, self-efficacy can manifest as a farmer's belief that they have sufficient skills or personal capabilities, for example, to adopt new cultivation techniques or crops. Optimism can also be seen as an essential element of an entrepreneurial identity. According to Puri and Robinson (2007), more optimistic people are more likely to be entrepreneurs, but extreme optimists have the tendency to make too risky decisions. They keep pursuing goals even with little chance of success (Åstebro et al., 2007). On the other hand, a reasonable amount of optimism is a sign of belief in one's success and thus a requirement for persistence (Vesala et al., 2007). Demanding crops such as protein crops require resilience and optimism from farmers as cultivation can face difficulties and yields can be poor (Suvanto et al., 2018).

To summarise, we regard an entrepreneurial identity as a multidimensional construct, consisting of mutually reinforcing dimensions of entrepreneurial and personal orientations. Based on the previous theorization, we suggest that research is needed to examine how an entrepreneurial identity influences farmers' crop cultivation choices. We understand risk-taking, innovativeness and growth orientation as dimensions expected to drive entrepreneurial orientation, while personal control, selfefficacy and optimism are the dimensions expected to drive personal orientation. The effects are 
demonstrated in Figure 1. The continuous arrows represent relationships where the positive correlations are expected.

----Insert Figure 1 here ----

\section{Material and methods}

\subsection{Survey instrument and sample}

A structured questionnaire to elicit farmers' views was developed and distributed to 2,000 farmers in the provinces of South Ostrobothnia and Central Finland in July 2017. The homogeneity of the study provinces, and the whole Finland, implies similarity between regions in exogeneous characteristics such as market structures, agricultural and environmental policies applied to farming and climatic conditions. The sample was a weighed random sample of farms in the Finnish farm registry and that had allowed their e-mail contact information to be used for research purposes. The sample included all farms in the two provinces that had cultivated faba bean, pea or protein-rich special crops in 2016 (206 farms), or which had raised pigs or poultry (356 farms, some farms which were also cultivating the crops mentioned above). Other farms in the sample were randomly selected by stratifying the sample according to four farm-size categories. The questionnaire was prepared using Webropol software and distributed by email to the respondents. Two reminders were sent to persons who had not responded by the deadline for submission.

The survey included questions on which crops the farmer had cultivated, farm characteristics and factors that the farmer considered to have influenced their crop decisions and entrepreneurial identity. The unit of observations was an individual farmer. The literature was explored to obtain information on the key constructs and scales appropriate for measuring entrepreneurial identity 
through entrepreneurial orientation and personal orientation. The survey instrument was developed in several stages following questions presented, for instance, by the social-psychology research group at the University of Helsinki (Vesala and Vesala, 2010; Vesala et al., 2007) and by Van Dyne and Pierce (2003). Five-point Likert scales were used to minimize executive response time and effort. The questionnaire consisted of 20 claims. The entrepreneurial orientation claims concerned risk-taking, innovativeness, and growth, while the personal orientation claims concerned optimism, self-efficacy and personal control.

\subsection{Description of the data}

The data collection yielded 308 completed questionnaires, which corresponded to a participation rate of $15.4 \%$. In all, $54 \%$ of respondents had cultivated oilseeds, and $42 \%$ legumes. Table 1 shows the percentage of respondents by age class, education, annual turnover and proportion of turnover generated by crop production, province, and whether livestock were kept on the farm. The annual turnover of the farm was less than $€ 50,000$ for $40 \%$ of respondents and over $€ 150,000$ for $28 \%$ of respondents. As the average total output was $€ 105,208$ per farm in Finland in 2016 (Luke, 2019), the data were relatively representative in terms of turnover generated. Almost $40 \%$ of respondents obtained $80-100 \%$ of their turnover from crop production, while $34 \%$ of respondents earned less than $20 \%$ of their turnover in this way.

About $60 \%$ of respondents were $40-59$ years of age. The respondents were slightly younger than the average farmer in Finland (52 years), but given the emphasis on crops cultivated and livestock kept, the age of the respondents was quite representative of the farm population in Finland. About onethird of respondents had a professional education in agriculture, but only $17 \%$ had a higher education. The respondents were more educated than the typical farmer in Finland and farms which had replied 
the survey were somewhat larger than the average farm in the original sample ( 59 ha vs. 52 ha). About two-thirds of respondent farms raised cattle, $12 \%$ pigs, $4 \%$ broilers and $6 \%$ chickens. There was an overrepresentation of livestock farmers in the data, as about two-thirds of Finnish farms have crop farming as their main production line (Luke, 2017).

----Insert Table 1 here ----

\subsection{Statistical analysis}

The respondents were firstly categorized into two contrasting groups according to six dimensions of entrepreneurial identity. These dimensions were:

1) Innovativeness (innovative vs. non-innovative)

2) Risk-taking (risk-seeking vs. risk-averse)

3) Growth (growth-oriented vs. stagnant)

4) Self-efficacy (skilled vs. non-skilled)

5) Optimism (optimistic vs. pessimistic)

6) Personal control (influential vs. non-influential)

The categorization was a binary variable based on the responses that each person had provided to questions associated with these six orientation characteristics. K-means clustering was used to identify group memberships for each respondent, because it is a method that can group individual observations without any prior knowledge of relationships between the groups or individuals. A fitted value for membership in six contrasting groups was saved and used in the subsequent analysis. Secondly, six logistic regression models were estimated to describe how predetermined demographic variables (factors or covariates) such as the respondent's education, farm size (logarithmic transformation of hectares cultivated), years of experience in farming, province where the farm was 
located, and whether the farm had livestock contributed to the likelihood of a respondent being associated with the groups of innovative, risk-seeking, growth-oriented, optimistic, skilful or influential farmers. Logistic regression was used because it is suited analyse how a dichotomous dependent variable is associated with independent variables. Explanatory performance of different model specifications were investigated in order to select the most robust model. Backwards conditional elimination was used to exclude factors and covariates that were statistically insignificant at a $10 \%$ risk level. The estimates were then converted to odds ratios, which make it more intuitive to interpret the results of logistic regression models. The final model specifications are presented in the results section.

Thirdly, cultivation patterns for respondents belonging to each identified group were described. To complement statistical analyses, cross-tabulation was used to describe the proportion of farmers cultivating or not cultivating a protein-rich crop. The cultivation of protein-rich crops was examined for two crop categories a) rapeseed and turnip rape, and b) legumes (pea, faba bean). For each crop category two descriptive analyses were conducted. First, it was examined whether the respondents had cultivated these crops in the past and, second, within those who had cultivated, whether they continued (or planned to continue) the cultivation. All analyses were conducted with IBM SPSS statistics (v25).

\section{Results}

\subsection{Categorization of respondents according to their entrepreneurial identity}

The clustering analysis identified whether the respondent was associated with the groups of innovative, risk-seeking, growth-oriented, optimistic, skilful or influential farmers. Hence, each 
respondent was assigned to the six groups. About half of the respondents were innovative and, in addition, risk-seeking, optimistic, skilled, influential or growth-oriented (Table 2). As a result, innovative respondents were also likely to have other characteristics associated with an entrepreneurial identity. The models correctly classified at least two-thirds of respondents in all six categories. However, the model performance in identifying non-innovative of non-influential respondents was poor, around $10 \%$, which implies that the explanatory variables were unable to fully identify these categories (Table 3).

----Insert Table 2 here ----

The logistic regression results in Table 3 indicated that farm size was a highly significant factor regarding a respondent's identity group. The larger the farm, the more likely they belonged to innovative, risk-seeking, growth-oriented, optimistic, skilful or influential groups. Furthermore, if the farm was in the largest $10 \%$, they were 2.4 times more likely to cultivate protein-rich crops compared to smaller farms. Respondents between 30 and 39 years of age were more likely to be innovative, but also more likely to feel they could not influence their farm's success through their own actions compared to older respondents. There was a tendency ( $p$-value higher than 0.05 but lower than 0.1 ) suggesting that respondents aged 39 or less may be more growth-oriented than older respondents aged 40 to 59 years. Respondents with a low level of education, especially those without any kind of formal professional education, were more likely to be pessimistic than respondents with an academic education. Less educated persons may also associate themselves with being less skilled professionally as farmers.

Full-time farmers were more likely to belong to the group of skilled and optimistic farmers than parttime farmers. Farms raising pigs were more likely to be risk-seeking, while cattle farms and farms 
producing poultry meat were more likely to be growth-oriented than farms not pursuing these types of animal production. The youngest respondents were more likely to be innovative, growth-oriented and optimistic than their oldest counterparts.

----Insert Table 3 here ----

\subsection{Factors related to protein crop cultivation}

Table 4 and Figure 2 show the cultivation patterns of farmers by their entrepreneurial profile. A higher proportion of respondents belonging to innovative, risk-seeking, growth-oriented, optimistic, skilful or influential groups cultivated oilseeds and/or legumes than in the non-innovative, risk-averse, stagnant, pessimistic, non-skilled or non-influential groups. For instance, $26 \%$ of risk-averse farmers had cultivated legumes compared with $52 \%$ of farmers assigned to the risk-seeking group. By contrast, the willingness of those farmers who had already cultivated legumes or oilseeds to continue cultivation in the future did not seem to differ substantially between contrasting groups. For instance, $84 \%$ of risk-seeking farmers who had cultivated legumes intended to continue cultivation in the future, and $76 \%$ of risk-averse farmers who had cultivated legumes also intended to continue.

----Insert Table 4 here ----

When comparing the entrepreneurial characteristics of each respondent group, farmers who had cultivated both oilseeds and legumes were more entrepreneurially oriented than farmers who had cultivated neither of these crops. The difference was substantial in all six dimensions, although not statistically significant in some cases. In particular, they differed by the risk-taking dimension. The 
spider diagram in Figure 2 illustrates that a higher proportion of entrepreneurially oriented farmers cultivated both legumes and oilseeds compared with non-entrepreneurially oriented farmers. Table 4 suggests that while entrepreneurial identity was related to the decision to begin cultivating proteinrich crops, the decision to discontinue cultivating these crops was mostly determined by other factors such as profitability and previous experiences of cultivation. In total, $38 \%$ and $30 \%$ of all respondents were planning to continue the cultivation of oilseeds and legumes, respectively, in the future.

Farmers who had cultivated both legumes and oilseeds had a substantially stronger entrepreneurial identity than farmers who had cultivated neither of these crops (Figure 2). By contrast, differences between farmers who had cultivated only oilseeds or only legumes were less evident. However, the percentages provided in Table 4 suggest that the incidence of oilseed cultivation was approximately 1.5-fold and the incidence of legume cultivation approximately two-fold among respondents having a strong entrepreneurial identity when compared with their contrast groups. In this respect, the results suggest that entrepreneurial identity can play a stronger role when farmers decide to start legume cultivation compared to deciding to start oilseed cultivation.

----Insert Figure 2 here ----

Table 5, however, suggests that risk-seeking and innovativeness play a significant role in legume cultivation. Innovative or risk-seeking farmers were substantially more likely to cultivate legumes than risk-averse or non-innovative respondents, whereas these characteristics did not have a statistically significant contribution to the decision to begin oilseed cultivation. By contrast, personal control did contribute to this decision.

Table 5 shows an estimation of the results regarding how different explanatory variables explained the likelihood that the respondent had started to cultivate oilseeds or legumes. The likelihood that a 
respondent had cultivated oilseeds was higher among farms that generated the majority of their turnover from crop production; farms that raised poultry for meat; and among respondents who considered themselves able to influence the success of their farm when compared with farms and farmers without these characteristics. The likelihood was also higher the larger the farm, or the longer the respondent had been farming.

The likelihood that a respondent had cultivated legumes was on larger farms compared with smaller farms; and on farms raising cattle compared with farms without cattle. A $21-40 \%$ share of income generated by crop production also seemed to be associated with an increased likelihood of cultivating legumes. Respondents who were classified in risk-seeking or innovative groups had about twice the likelihood of having cultivated legumes than respondents who did not belong to either of these groups (Table 5).

----Insert Table 5 here ----

\subsection{Future plans regarding the cultivation of protein-rich crops}

The analysis indicated that entrepreneurial and demographic factors did not directly contribute to whether a farmer had decided to continue or discontinue cultivation of a specific crop. The survey included a follow-up question where the respondents were asked to assess the importance of ten factors when deciding whether to cultivate a crop. Factors related to profitability, price of yield and realization of risks were stated to be the most important factors influencing the decision to continue or discontinue cultivating a specific crop.

While $55 \%$ to $60 \%$ of the respondents assigned to the risk-seeking, optimistic, skilled or innovative group agreed or strongly agreed with the statement that they had sufficient information and skills to 
produce protein crops, only $30 \%$ to $40 \%$ of respondents associated with opposite groups and not believing in their ability to exert an influence were of this opinion. Hence, an entrepreneurial identity was also associated with perceptions regarding the level of know-how of farmers.

\section{Discussion}

The study examined the relationship between entrepreneurial identity and the cultivation choices made by farmers in protein crop cultivation in Finland. Entrepreneurial identity was examined alongside other factors relating to the farmers and farms - size, age, education, production line and cultivated crops - in an attempt to understand and predict the key issues influencing the likelihood of protein crop cultivation choices. We assumed that farmers with a higher propensity for an entrepreneurial identity would be more likely to cultivate protein-rich crops.

In Finland, as well as other European countries, the role of farmers has been under reconstruction within the EU and national policies during recent decades. Even though balancing between the roles of entrepreneur and producer can be confusing, it is still a part of contemporary agriculture. Our results confirm previous results in that the entrepreneurial identity is familiar and established among Finnish farmers (e.g. Niska et al., 2012; Stenholm and Hytti, 2014). We can conclude that there is a difference between entrepreneurial farmers and food producers, particularly in relation to risk-taking and innovativeness (e.g. McElwee, 2006; Silvasti, 2009). The results also show that our assumption about the connection between entrepreneurial identity and protein-rich crop cultivation decisions was correct: Farmers with a higher entrepreneurial identity, especially a propensity for risk-taking and innovativeness, are more likely to begin cultivating oilseeds and legumes compared with those with a 
lower entrepreneurial identity. An entrepreneurial identity seems to be strongest among farmers who cultivate legumes, and even higher if they cultivate both legumes and oilseeds.

When farmers with legume and oilseed cultivation were compared, some differences were found: while legume farmers scored particularly high in risk-seeking and innovativeness, oilseed farmers had a stronger belief in their influence on the farm's success. The oilseed farmers were also older and had larger farms than the legume farmers. These results aptly depict the oilseed cultivation situation in Finland: oilseeds are typically more familiar than legumes, farmers have more experience and markets are more stable (Suvanto et al., 2018). Therefore, we suggest that farming oilseed represents a smaller risk for farmers compared with legumes, and hence farmers with a lower entrepreneurial identity also dare to cultivate them. A similar situation may develop with legumes, especially if they are payed more than other crops. Roussy et al. (2018) found that high yield expectations and a better price increase the probability of adopting more risky cultivation strategies. However, rather small proportion of farms specialize in crops such as oilseeds and especially legumes. Instead, the larger dairy farms, for example, may specialize in production of grass, which is an important source of protein for cattle (Niemi and Pietola, 2001).

Our results reinforce the previous views (e.g. González and Benito, 2001; Vesala and Vesala, 2010) that entrepreneurial identity is stronger among farmers with larger farms. However, the causality is complex. Have the farms grown because of the farmers' entrepreneurial identity or does the large size cause or reinforce this identity? Stenholm and Hytti (2014) point out that not all farmers with large farms are entrepreneurially oriented. Instead, growth can be a sign of decent viability, and necessary for survival. Farmers with large farms are, however, more likely to continue farming (Viira et al., 2014) and they can spread their risks by diversifying cultivation to different crops. Thus, they have lower risks when it comes to experimenting with new or demanding plants like protein-rich crops (e.g. Feder and O'Mara, 1981), unlike farmers of small specialized farms, who may incur significant economic 
losses in relation to their turnover if the risks materialize. We suggest that farm size increases a farmer's feeling of personal power since the size decreases risks but increases opportunities and decision-making power. According Vesala and Peura (2005), owners of large farms with employees and multiple customers have a stronger sense of personal control and entrepreneurial orientation, and are therefore more motivated to expand. Although the entrepreneurial literature emphasizes the role of growth, a question still remains: Is the growth a sign of economic success in agriculture?

Previous studies have shown that entrepreneurial identity is stronger among younger farmers (González and Benito, 2001; Vesala and Vesala, 2010). We found that farmers between 30 and 39 are more likely to be innovative, risk-takers and growth-orientated. Comer et al. (1999) claim that a young age also relates to positive views on sustainability. This may reflect the change of values in agriculture. This is reassuring, as young and entrepreneurial farmers can be more receptive to innovations for sustainable development. We found that young farmers believe less in their influence through their own actions than older farmers do. Between the ages of 30 and 39, farmers in Finland have usually been farm-owners for just a few years and this lack of experience may make them feel less selfconfident than their older and more experienced counterparts. Farms are typically family-owned and therefore young farmers may have long farming experience, but less management experience. The continuity of generations on family farms may also restrain a farmer's decision-making power. McElwee and Robson (2005), for example, observed that the motivation of farmers on family farms is not always financial, and not all of their actions are entrepreneurial. In Finland some ideas of peasantry, such as an appreciation of generational continuity with regard to farming, are still strongly embedded in the agriculture (Hangasmaa, 2011; Silvasti, 2009).

It has been stated that growth-oriented entrepreneurs are more highly educated than the average entrepreneur (Autio, 2007; Pindado and Sánchez, 2018). Higher education seems to increase selfconfidence. Less educated farmers were more likely to be pessimistic and classified themselves as less 
skilled professionally. Farmers with a Master's degree in agriculture are more likely to cultivate legumes, which are seen as new, challenging crops that call for more knowledge and skills. Farmers belonging to the risk-seeking, optimistic, skilled or innovative groups stated that they had a sufficient level of information and skills to produce protein crops, whereas the level was much lower among farmers with a low entrepreneurial identity. Indeed, the previous literature states that entrepreneurs with a higher-level degree have acquired more knowledge and adopted multiple styles of learning that can be translated into managerial and practical skills (Barbieri and Mshenga, 2008). Rosairo and Potts (2016) emphasize the role of education in agriculture, claiming that entrepreneurial attitudes are determined by education rather than age. Suvanto et al. (2018) point out that farmers have recognized the demands of consumers and the environment but they have challenges when it comes to obtaining knowledge and training for protein-rich cultivation in Finland. We suggest that to enhance sustainable agriculture, farmers need to have the education and capabilities to perceive opportunities but also to adapt to the changing environment (e.g. Grande et al., 2011; Dias et al. 2019b). Thus, the role of education in farmers' strategic management decisions should not be understated.

\section{Conclusions}

The aim of this study was to examine the impact of entrepreneurial identity on cultivation decisions. We conclude that farmers with a high entrepreneurial identity are more likely to begin protein-rich crop cultivation. Up to now, profitable but risky and demanding crops have largely tempted farmers with a high entrepreneurial identity, although the vision for more sustainable and self-contained European agriculture will require that protein-rich crop cultivation becomes mainstream. To boost farmers' interest in protein crop cultivation, stronger institutional and agricultural policy support is needed. Particularly farmers with a low entrepreneurial identity need developed and stable market structures, robust protein crop varieties, long-term policy outlook and incentives. We suggest that agricultural policy incentives may not be effective if they do not reflect the needs and motivations of 
different farmers. For example, environmentally conscious farmers and organic farmers can be motivated by highlighting the positive environmental outcomes and crop rotation aspects. Policy makers are recommended to ensure that farmers with a high entrepreneurial identity continue protein crop cultivation for example, by emphasizing the economic advantages of soil condition and pre-crop value and supporting the Nordic protein crop breeding. While farming conditions may vary across Europe, the challenges are partially the same and especially in the Northern European conditions, similar recommendations regarding policies and knowledge sharing may be applicable.

Entrepreneurial farmers are innovative and shape markets rather than being governed by them. The forerunner farmers can create new markets and implement competitive strategies: they can operate as processors to enhance local markets, collaborate with livestock farms, operate as suppliers and develop their own usage. They challenge the typical role of processor-farmer by encouraging other farmers to start protein-rich crop cultivation. The entrepreneurial role of protein-rich crop farmers could also be utilized more efficiently to reduce uncertainty and promote the efficient exchange of experiences. In the context of agriculture, the method of learning-by-doing has always been appreciated and hence the forerunner farmers should be encouraged to share their know-how by providing practical information on protein-rich crop cultivation techniques. People can learn, adapt and develop, but the key issue is that farmers need to develop entrepreneurial skills and competences to remain competitive and resilient in the future.

\section{Limitations}

Although this research provides interesting findings on farmers' entrepreneurial identity, some limitations are to be acknowledged. Our data originated from Finnish farms. Hence, the findings should be generalized to non-comparable populations with caution. While the common agricultural 
policy is applied across the EU, farming conditions, the details of policies applied and market opportunities may vary by country, which may twist the decision-making framework and impact the importance entrepreneurial orientation if similar study was conducted in different conditions. The results are also conditional on parameters that have been obtained and the representativeness of the data compared with the underlying population. While actions were taken to ensure that the dataset represented farmers in the study region, innovative and entrepreneurially oriented farmers may have been overpresented in the final dataset as they may be more eager to respond to surveys, thus contributing to the amount of information available on passive farmers. There was no public information about the prices of specialty crops offered to farmers therefore the impacts of prices could not be tested in this dataset. With more detailed information about farming conditions faced by each farmer, the performance of the logistic models to identify each farmers' group membership could have been further increased.

During the period when the survey data were collected, there was a public discussion on whether neonicotinoid insecticides will be banned in the EU. This may have influenced respondents' interest in the cultivation of rapeseed because neonicotinoids play an important role in protecting rapeseed against pests, and there are no effective substitutes available. The dimensions of entrepreneurial orientation, locus of control and self-efficacy used in the study do not cover all strategic and personal elements that have been connected with entrepreneurship in the literature. We suggest, however, that the dimensions used in this study represent the core of the discussions concerning the nature of entrepreneurialism. To this end, we were specific about using tested claims and theories when designing the questionnaire.

\section{Acknowledgement}

We want to thank (name is removed because of blinded review. Will be added later) for her contribution to this article. 


\section{References}

Arthurs, J. D. and Busenitz, L. W. (2006) ‘Dynamic Capabilities and Venture Performance: The Effects of Venture Capitalists', Journal of Business Venturing 21: 195-215.

Åstebro, T., Jeffrey, S. A., and Gordon, A. (2007). Inventor Perseverance after Being Told to Quit: The Role of Cognitive Biases. Journal of Behavioral Decision Making, 20(3), 253-272.

Autio, E. (2007). Global entrepreneurship monitor: 2007 global report on high growth entrepreneurship. Wellesley, MA/London: Babson College and London Business School.

Bandura, A. (1977). Self-efficacy: Toward a unified theory of behavioral change. Psychological Review, 84(2), 191-215.

Bandura, A. (1986). The explanatory and predictive scope of self-efficacy theory. Journal of social clinical psychology, 4(3), 359-373.

Bandura, A. (1997). Self-Efficacy: The Exercise of Control. New York: W H. Freeman.

Barbieri, C., and Mshenga, P. M. (2008). The role of the firm and owner characteristics on the performance of agritourism farms. Sociologia Ruralis, 48(2), 166-183.

Bird, B. (1989). Entrepreneurial behavior. Glenview, IL: Scott Foresman.

Boyd, N. G., and Vozikis, G. (1994). The influence of self-efficacy on the development of entrepreneurial intentions and actions. Entrepreneurship theory practice, 18(4), 63-77.

Bues, A., Preißel, S., Reckling, M., Zander, P., Kuhlman, T., Topp, K., ... Murphy-Bokern, D. (2013). The environmental role of protein crops in the new common agricultural policy. Directorate general for internal policies, Policy department B: Structral and cohesion policies, Agriculture and rural development Retrieved from http://www.europarl.europa.eu/RegData/etudes/etudes/join /2013/495856/IPOLAGRI_ET(2013)495856_EN.pdf. 
Burton, R.J. and Wilson, G.A., (2006). Injecting social psychology theory into conceptualisations of agricultural agency: towards a post-productivist farmer self-identity?. Journal of Rural Studies, 22(1), 95-115.

Carland, J. W., Hoy, F., Boulton, W. R., and Carland, J. C. (1984). Differentiating entrepreneurs from small business owners: A conceptualization. Academy of Management Review, 9(2), 354359.

Carter, S., and Rosa, P. (1998). Indigenous Rural Firms: Farm Enterprises in the UK. International Small Business Journal, 16(4), 15-27.

Chen, C. C., Greene, P. G., and Crick, A. (1998). Does entrepreneurial self-efficacy distinguish entrepreneurs from managers? Journal of Business Venturing, 13(4), 295-316.

Comer, S., Ekanem, E., Muhammad, S., Singh, S. P., and Tegegne, F. (1999). Sustainable and conventional farmers: A comparison of socio-economic characteristics, attitude, and beliefs. Journal of Sustainable Agriculture, 15(1), 29-45.

Covin, J. G., and Slevin, D. P. (1991). A conceptual model of entrepreneurship as firm behavior. Entrepreneurship Theory and Practice, 16(1), 7-26.

De Rosa, M., McElwee, G. and Smith, R., (2019). Farm diversification strategies in response to rural policy: a case from rural Italy. Land use policy, 81, 291-301.

Dias, C. S., Rodrigues, R. G., and Ferreira, J. J. (2019a). What's new in the research on agricultural entrepreneurship? Journal of Rural Studies, 65, 99-115.

Dias, C. S., Rodrigues, R. G., and Ferreira, J. J. (2019b). Agricultural entrepreneurship: Going back to the basics. Journal of Rural Studies (article in press).

Feder, G., and O'Mara, G. T. (1981). Farm size and the diffusion of green revolution technology. Economic Development and cultural change, 30(1), 59-76.

Fitz-Koch, S., Nordqvist, M., Carter, S., and Hunter, E. (2018). Entrepreneurship in the agricultural sector: A literature review and future research opportunities. Entrepreneurship Theory and Practice, 42(1), 129-166. 
Gellynck, X., Cárdenas, J., Pieniak, Z., and Verbeke, W. (2015). Association between innovative entrepreneurial orientation, absorptive capacity, and farm business performance. Agribusiness, 31(1), 91-106.

González, J. J., and Benito, C. G. (2001). Profession and identity. The case of family farming in Spain. Sociologia Ruralis, 41(3), 343-357.

Goodland, R. (1997). Environmental sustainability in agriculture: Diet matters. Ecological Economics. $23,189-200$.

Grande, J., Madsen, E. L., and Borch, O. J. (2011). The relationship between resources, entrepreneurial orientation and performance in farm-based ventures. Entrepreneurship and Regional Development, 23(3-4), 89-111.

Hangasmaa, L. (2011). Maanviljelyn kulttuurinen kestävyys - Määrittelyn ja mittaamisen haasteita. Maaseudun uusi aika - Maaseutututkimuksen ja -politiikan aikakauslehti, 19(1), 61-70.

Hughes, M., and Morgan, R. E. (2007). Deconstructing the relationship between entrepreneurial orientation and business performance at the embryonic stage of firm growth. Industrial Marketing Management, 36, 651-661.

Kaukovirta-Norja, A., Leinonen, A., Mokkila, M., Wessberg, N., and Niemi, J. (2015). Tiekartta Suomen proteiiniomavaraisuuden parantamiseksi. VTT visions 6. Retrieved from Espoo: http://www.vtt.fi/inf/pdf/visions/2015/V6.pdf.

Luke. (2017). Structure of agricultural and horticultural enterprises 2016. Retrieved 21.2.2019 http://stat.luke.fi/maatalous-ja-puutarhayritysten-rakenne-2016_fi.

Luke. (2018). Suomen maa- ja elintarviketalous 2018. Retrieved from Helsinki: https://jukuri.luke.fi/handle/10024/542199.

Luke. (2019). Economydoctor: total output. FADN Standard Results Retrieved 21.2.2019 https:// portal.mtt.fi/portal/page/portal/economydoctor/eufadnstandard_so/timeline/total_output. 
Lumpkin, G. T., and Dess, G. G. (1996). Clarifying the Entrepreneurial Orientation Construct and Linking It To Performance. Academy of Management Review, 21(1), 135-172. doi:10.5465/amr.1996.9602161568.

Mainemelis, C., Boyatzis, R. E., and Kolb, D. A. (2002). Learning styles and adaptive flexibility: Testing experiential learning theory. Management learning, 33(1), 5-33.

Mc Fadden, T., and Gorman, M. (2016). Exploring the concept of farm household innovation capacity in relation to farm diversification in policy context Journal of Rural Studies, 46, 60-70.

McCelland, D. C. (1961). Psychology's Role in Economic Development.(Book Reviews: The Achieving Society). Science, 134, 1608-1609.

McElwee, G. (2006). Farmers as entrepreneurs: developing competitive skills. Journal of developmental entrepreneurship, 11(3), 187-206.

McElwee, G., and Robson, A. (2005). Diversifying the farm: opportunities and barriers. Journal of Rural Research and Policy(4), 84-96.

McElwee, G., and Smith, R. (2012). Classifying the strategic capability of farmers: a segmentation framework. International Journal of Entrepreneurial Venturing, 4(2), 111-131.

McNally, S. (2001). Farm Diversification in England and Wales - What We Can Learn from the Farm Business Survey. Journal of Rural Studies, 17(2), 247-257.

Miller, D. (1983). The correlates of entrepreneurship in three types of firms. Management Science, 29(7), 770-791.

Mishra, A. K., and Lence, S. H. (2005). Risk management by farmers, agribusinesses, and lenders. Agricultural Finance Review, 65(2), 131-148.

Niemi, J. K., and Pietola, K. (2001). Land use response to agricultural policy and market movements on Finnish dairy farms. Agricultural and Food Sciencein Finland, 10, 285-294.

Niska, M., Vesala, H. T., and Vesala, K. M. (2012). Peasantry and entrepreneurship as frames for farming: reflections on farmers' values and agricultural policy discourses. Sosiologia ruralis, 52(4), 453-469. 
Nousiainen, M., Pylkkänen, P., Saunders, F., Seppänen, L., and Vesala, K. M. (2009). Are Alternative Food Systems Socially Sustainable? A Case Study from Finland. Journal of Sustainable Agriculture, 33(5), 566-594. doi:10.1080/10440040902997819.

Pahkala, K. (1989). Öljykasvien viljelyn edistäminen - Yhteistutkimuksen tuloksia vuosilta 1985 - 1988 In K. Pahkala (Ed.): Maatalouden tutkimuskeskus. Tiedote 11/89, Jokioinen.

Peltonen-Sainio, P., Jauhiainen, L., Valaja, J., Voutila, L., Hannukkala, A., Huusela-Veistola, E., .. . Niemi, J. (2013). Potential and realities of enhancing rapeseed- and grain legume-based protein production in a northern climate. Journal of Agricultural Science, 151(3), 303-321. Peltonen-Sainio, P., and Niemi, J. K. (2012). Protein crop production at the northern margin of farming: to boost or not to boost. Agricultural and Food Science, 21, 370- 383.

Peterson, C., and Stunkard, A. J. (1992). Cognates of personal control: Locus of control, self-efficacy, and explanatory style. Applied preventive psychology, 1(2), 111-117.

Phillipson, J., Gorton, M., Raley, M., and Moxey, A. (2004). Treating Farms as Firms? The Evolution of Farm Business Support from Productionist to Entrepreneurial Models. Environment and Planning C: Government and Policy, 22(1), 31-54. doi:https://doi.org/10.1068/c0238.

Pindado, E., and Sánchez, M. (2018). Growth-oriented new agricultural ventures: the role of entrepreneurial resources and capabilities under convergence forces. European Review of Agricultural Economics, 1-34.

Puri, M., and Robinson, D. T. (2007). Optimism and Economic Choice. Journal of Financial Economics, 86(1), 71-99.

Rauch, A., and Frese, M. (2007). Let's put the person back into entrepreneurship research: A metaanalysis on the relationship between business owners' personality traits, business creation, and success. European Journal of Work and Organizational Psychology, 16(4), 353-385.

Rizov, M., and Mathijs, E. (2003). Farm survival and growth in transition economies: theory and empirical evidence from Hungary. Post-Communist Economies, 15(2), 227-242. 
Robinson, P., Stimpson, D., Huefner, J., and Hunt, H. (1991). An attitude approach to the prediction of entrepreneurship. Entrepreneurship Theory \& Practice, 15, 13-31.

Robson, M. C., Fowler, S. M., Lampkin, N. H., Leifert, C., Leitch, M., Robinson, D., . . Litterick, A. M. (2002). The agronomic and economic potential of break crops for ley/arable rotations in temperate organic agriculture (Vol. 77): Academic Press.

Rosairo, H. R., and Potts, D. J. (2016). A study on entrepreneurial attitudes of upcountry vegetable farmers in Sri Lanka. Journal of Agribusiness in Developing Emerging Economies, 6(1), 39-58.

Rotter, J. B. (1966). Generalized expectancies for internal versus external control of reinforcement. Psychological Monographs: General and Applied, 80(1), 1-27.

Roussy, C., Ridier, A., Chaib, K., and Boyet, M. (2018). Marketing contracts and risk management for cereal producers. Agribusiness, 34(3), 616-630. doi:10.1002/agr.21549.

Rubiales, D., and Mikic, A. (2015). Introduction: Legumes in Sustainable Agriculture. Critical Reviews in Plant Sciences, 34(1-3), 2-3. doi:10.1080/07352689.2014.897896.

Shane, S. (2003). A General Theory of Entrepreneurship. Northampton, MA: Edward Elgar Publishing.

Sillero, J. C., Villegas-Fernández, A. M., Thomas, J., Rojas-Molina, M. M., Emeran, A. A., FernándezAparicio, M., and Rubiales, D. (2010). Faba bean breeding for disease resistance. Field Crops Research, 115(3), 297-307.

Silvasti, T. (2009). Giving up the family farm - An alternative story of the structural change in agriculture in Finland. Maaseudun uusi aika - Maaseutututkimuksen ja -politiikan aikakauslehti, 2(2009), 21-32.

Stagnari, F., Maggio, A., Galieni, A., and Pisante, M. (2017). Multiple benefits of legumes for agriculture sustainability: an overview. Chemical and Biological Technologies in Agriculture, $4(1), 1-13$.

Steiner, B. E. (2017). A phenomenon-driven approach to the study of value creation and organizational design issues in agri-business value chains. Econ. Agro-Aliment./Food Econ., 19, 89-118. 
Stenholm, P., and Hytti, U. (2014). In search of legitimacy under institutional pressures: A case study of producer and entrepreneur farmer identities. Journal of Rural Studies, 35, 133-142.

Stevenson, H. H., and Jarillo, J. C. (2007). A Paradigm of Entrepreneurship: Entrepreneurial Management. Strategic Management Journal, 15, 521-536.

Stevenson, H. H., and Jarrillo-Mossi, J. C. (1986). Preserving entrepreneurship as companies grow. Journal of Business Strategy, 6, 10-23.

Stoddard, F. L., Hovinen, S., Kontturi, M., Lindström, K., and Nykänen, A. (2009). Legumes in Finnish agriculture: history, present status and future prospects. Agricultural and Food Science, 18, 191-205.

Suvanto, H., Lähdesmäki, M., and Enbuska, M. (2018). Valkuaiskasvien markkinat. In Valkuaiskasveista Voimaa. Tuota Valkuaista -hankkeen loppujulkaisu Kekkonen H., Niemi J., Heinola K., Liu X., Sipilä A., Tuomisto J., Suvanto H., Lähdesmäki M., Enbuska M., Niskanen M., Laitila N. and Vihonen E. (pp. 70). Helsinki, Finland: Luonnonavarakeskus.

Thompson, N. M., Bir, C., and Olynk Widmar, N. J. (2019). Farmer perceptions of risk in 2017. Agribusiness, 35(2), 182-199. doi:10.1002/agr.21566.

Trujillo-Barrera, A., Pennings, J. M., and Hofenk, D. (2016). Understanding producers' motives for adopting sustainable practices: the role of expected rewards, risk perception and risk tolerance. European Review of Agricultural Economics, 43(3), 359-382.

Van Dyne, L., and Pierce, J. L. (2003). Psychological ownership: Feelings of possession and workplace attitudes and behavior. Working paper, Eli Broad School of Management, Michigan State University.

Veidal, A., and Flaten, O. (2014). Entrepreneurial orientation and farm business performance: the moderating role of on-farm diversification and location. International Journal of Entrepreneurial Innovation, 15(2), 101-112. 
Verhees, F. J. H. M., Kuipers, A., and Klopcic, M. (2011). Entrepreneurial Proclivity and Farm Performance:The Cases of Dutch and Slovenian Farmers. 12(3), 169-177. doi:10.5367/ijei.2011.0039.

Vesala, H., and Vesala, K. M. (2010). Entrepreneurs and producers: identities of Finnish farmers in 2001 and 2006 Journal of Rural Studies, 26, 21-36.

Vesala, K. M., and Peura, J. (2005). Presentation of personal control in the rhetoric of farm families engaged in business diversification in Finland. Journal of comparative family studies, 443473.

Vesala, K. M., Peura, J., and McElwee, G. (2007). The split entrepreneurial identity of the farmer. Journal of Small Business and Enterprise Development, 14(1), 48-63.

Viira, A.-H., Pöder, A., and Värnik, R. (2014). Discrepancies between the Intentions and Behaviour of Farm Operators in the Contexts of Farm Growth, Decline, Continuation and Exit-Evidence from Estonia. German Journal of Agricultural Economics, 63(670-2016-46000), 46.

Wiklund, J., and Shepherd, D. (2005). Entrepreneurial orientation and small business performance: a configurational approach. Journal of Business Venturing, 20(1), 71-91.

Woldesenbet, K., Ram, M., and Jones, T. (2011). Supplying large firms: The role of entrepreneurial and dynamic capabilities in small businesses. International Small Business Journal, 30(5), 493-512.

Zhao, H., and Seibert, S. E. (2006). The big five personality dimensions and entrepreneurial status: A meta-analytical review. Journal of Applied Psychology, 91(2), 259. 